\title{
The Changing Role of Missionary Societies in Africa
}

A pAPER on this subject was given to the Commonwealth Section of the Royal Society of Arts, London, by the Rev. Canon J. S. Kingsnorth, General Secretary, Universities' Mission to Central Africa, on 29 November 1962, with Mr. Philip Mason, Director of the Institute of Race Relations, in the Chair.

Canon Kingsnorth began by describing the early mission-states or stations which took African converts out of their own environment and often uprooted them from their background of tribal solidarity. The weakness of this early method was its rejection of African culture, which was regarded as too barbaric to be sublimated into a Christian and civilized way of life. In the next stage schools and hospitals were developed and missions expanded under the protection of the peace and order enforced by the ruling powers. But the association of Church and State was one of convenience only, and the struggle to demonstrate this is the essence of the crisis the Church is facing in Africa today. The important schools which grew up in Central and East Africa at this time have produced many of the leaders of the newly independent countries, who are thus men of Christian culture. On the other hand, most of the best scholars became teachers, and in the present crisis, when the Church needs educated leaders, very few of the African priests or ministers have any secondary education.

The missionary societies are now in the handing-over period. Most missionaries welcome the new governments and want to co-operate with them, and the missionary of today must identify himself with African aspirations. The Church in Africa now has its own governing bodies, officials, finance committees, ministers, priests, and bishops, and is independent of influence from abroad. Missionary societies have no say in the control of policy in the African Church. Their role is to act as 'prayer pressure-groups, fund-raisers, and recruiting agencies'. The need is for priests and ministers who will train African church leaders and for others who will do ordinary pastoral work under African supervision. Canon Kingsnorth foresaw groups of African Christians working on the missionary task in their own country and missionaries from abroad joining these groups and working in harness with the Africans. Similar groups in England will have African members. The permanent role of missionary societies is ' to organize the exchange of men and money this system necessitates, and the background of Christian prayet that must support it '.

\section{'The Journal of Modern African Studies'}

THrs new journal, edited by David and Helen Kimble, is to be published quarterly by the Cambridge University Press. The field of study will be modern Africa and the aim will be to bring together the best current work on a wide range of related subjects that have not hitherto found a common published forum. The main emphasis will be upon African politics and economics, peoples, policies, international relations, human geography, and social psychology. Litetary and cultural topics will also be dealt with occasionally. Interest will centre on the present day and on the many new societies which are evolving, rather than on archaeology, anthropology, history, and linguistics, which already have their own outlets for publication. The journal will be concerned not only with academic and specialist interests but also with promoting more informed general discussion of contemporary African affairs. An Editorial Advisory Board will be established, composed of specialists from the relevant fields of study and from as many different countries as may be appropriate.

Contributions to The Journal of Modern African Studies are invited from scholars all over the world. Accounts of original research and field-work in progress will be particularly welcomed, provided that their significance is of some general validity. It is hoped that many working in related fields will thus be brought into closer touch. Articles written in languages other than English will be considered on their merits, and where necessary transla- 
tion will be arranged. The average length suggested is 3,000 to 6,000 words, with occasional exceptions of up to 10,000 words. The price proposed is Ios. per copy, with an annual subscription of $30 s$. for four issues. All correspondence and contributions should be addressed to the Editors, The Journal of Modern African Studies, University Press, Cambridge, England.

\section{The 'Sierra Leone Language Revien,'}

THIs new journal is to be published annually by the Department of Modern European and African Languages, of the University College of Sierra Leone. The first number (1962) contains a Foreword by the Right Honourable Sir Milton Margai, M.B.E., an introduction by J. H. Gransden, and the following articles:

The Contribution of Freetown and Fourah Bay College to the P. E. H. Hair Study of West African Languages

Mid-Nineteenth Century Evidences of a Sierra Leone Patois

E. D. Jones

Temne, Landuma and the Baga Languages

A Bibliography of the Mende Language

W. A. A. Wilson

Language Distribution in Sierra Leone (with map)

P. E. H. Hair

T. D. P. Dalby

All communications should be forwarded to the Editor, Dr. T. D. P. Dalby, at the University College of Sierra Leone. The journal is distributed by Luzac \& Co. Ltd., 46 Great Russell Street, London, W.C. I, and the price is xos. $6 d$. (Sierra Leone only: $5 s$. .).

\section{'Homage to Africa'}

Mārg Publications 34-38 (Bank Street, Bombay) have devoted the June 1962 number of their magazine Pathway to African art, under the title 'Homage to Africa'. The editor, Mr. Mulk Raj Anand, has written an appreciation of the subject and there are also contributions from Mr. Tristan Tzara and Mr. James Johnson Sweeney. A tribal map of Africa is followed by over forty pages of photographs of sculpture and masks and there is a bibliography of some of the more important books on African art. Examples are illustrated from the following areas: Sudan, Sierra Leone, Ivory Coast, Ghana, Dahomey, Nigeria, Cameroons Grassland, Guinea Coast, and Congo. The price of Homage to Africa is Rs. 5.90.

\section{The Ghana Drama Studio}

THE Ghana Drama Studio, founded by Mrs. Efua Sutherland and directed by Mr. Joe de Graft, is associated with the Ghana Institute of Art and Culture and the Institute of African Studies (University of Ghana). It began in 1958 as a group of play-makers under the name of 'The Experimental Theatre Players'. Funds from the Government of Ghana and through the Arts Council of Ghana (now the Institute of Art and Culture) and from grants made by well-wishers abroad, including the Rockefeller Foundation, made it possible for the present building to be erected and equipped. The Drama Studio was declared formally open by Osagyefo, the President of Ghana, in October I 96r. With the introduction of Drama courses into the curriculum of the Institute of African Studies, it is envisaged that the Drama Studio will become part of the Institute, and it is at present running the Institute's preliminary part-time course in Drama, with the aid of lecturers from the university. Effective membership of the Drama Studio is now about fifty, drawn from a cross-section of the community; eleven plays have been presented, including a Twi adaptation of Everyman, a Tennessee Williams one-act play, and specially written plays in English and in Twi. 